OPEN ACCESS

Edited by:

Giovanni Li Volti,

Università degli Studi di Catania, Italy

Reviewed by:

Gabriele Multhoff,

Technische Universität München,

Germany

Anca Maria Cimpean,

University of Medicine and Pharmacy,

Romania

*Correspondence:

Matteo Donadon

matteo.donadon@hunimed.eu

Specialty section:

This article was submitted to Molecular and Cellular Oncology,

a section of the journal

Frontiers in Oncology

Received: 23 November 2017

Accepted: 09 May 2018

Published: 28 May 2018

Citation:

Donadon M, Lleo A, Di Tommaso L,

Soldani C, Franceschini B, Roncalli M and Torzilli G (2018) The Shifting Paradigm of Prognostic Factors of Colorectal Liver Metastases:

From Tumor-Centered to Host Immune-Centered Factors.

Front. Oncol. 8:181.

doi: 10.3389/fonc.2018.00181

\section{The Shifting Paradigm of Prognostic Factors of Colorectal Liver Metastases: From Tumor-Centered to Host Immune-Centered Factors}

\author{
Matteo Donadon ${ }^{1,2 *}$, Ana Lleo ${ }^{2,3}$, Luca Di Tommaso ${ }^{2,4}$, Cristiana Soldani ${ }^{1}$, \\ Barbara Franceschini ${ }^{1}$, Massimo Roncalli ${ }^{2,4}$ and Guido Torzilli',2
}

${ }^{1}$ Department of Hepatobiliary and General Surgery, Humanitas Clinical and Research Center, Rozzano, Italy, ${ }^{2}$ Department of Biomedical Science, Humanitas University, Rozzano, Italy, ${ }^{3}$ Department of Internal Medicine, Humanitas Clinical and Research Center, Rozzano, Italy, ${ }^{4}$ Department of Pathology, Humanitas Clinical and Research Center, Rozzano, Italy

The determinants of prognosis in patients with colorectal liver metastases (CLM) have been traditionally searched among the tumoral factors, either of the primary colorectal tumor or of the CLM. While many different scoring systems have been developed based on those clinic-pathological factors with disparate results, there has been the introduction of genetic biological markers that added a theranostic perspective. More recently, other important elements, such as those factors related to the host immune system, have been proposed as determinants of prognosis of CLM patients. In the present work, we review the current prognostic factors of CLM patients as well as the burgeoning shifting paradigm of prognostication that relies on the host immune system.

Keywords: host immune system, colorectal liver metastases, colorectal cancer liver metastases, colorectal cancer, immune response, immunotherapy

\section{INTRODUCTION}

Colorectal cancer is the third most common cancer as well as the second cause of cancer-related deaths worldwide (1). Being the liver the main filter of the venous drainage of the bowel, most of the patients with colorectal cancer develop colorectal liver metastases (CLM). Hepatic resection for CLM combined with systemic chemo-immunotherapy (SC) has the potential to be curative for patients with CLM, as this therapeutic approach has been associated with 5- and 10-year survival rates up to 50 and $35 \%$, respectively (2). Yet, in the recent years, SC has increasingly been used as part of a multidisciplinary strategy to select the most eligible candidates for surgical resection of CLM (3-5). Innovative and effective SC regimens, including oxaliplatin-based and irinotecan-based therapies with or without biological therapies using anti-vascular endothelial growth factor (VEGF) or anti-epidermal growth factor receptor (EGFR) inhibitors have changed the natural history of CLM (6). This has led to the opportunity to offer hepatic resection to a significant proportion of patients with advanced tumor burden, who would not have been considered for surgery until few years ago. To date, different score systems showing heterogeneous results have been developed to stratify prognosis of CLM patient's undergone hepatic resection (7-9). Nevertheless, in the era of precision medicine, there is still a strong need of new and reliable prognostic markers to cope with the high heterogeneity of CLM that is responsible for a wide spectrum of clinical presentations and different degrees of responsiveness to therapies. Among the variables contributing to the different clinical outcomes of CLM, host immune responses certainly play a pivotal role (10-13). In this 
article, we review the prognostic factors for patients undergoing hepatic resection for CLM focusing on the emerging shifting paradigm that concerns the role of the host immune system.

\section{DEMOGRAPHIC PROGNOSTIC FACTORS}

Gender and age are usually tested as prognostic factors in clinical studies. In general, gender does not significantly impact the outcome $(2,14,15)$, while age may have more influence. Yet, advanced age may be associated with increased operative risk and consequently with postoperative complications. Patients with complicated postoperative courses as well as with decompensated comorbidities are unlike to be able to complete the therapeutic program such as to start postoperative SC (16-19). Notably, a recent study on a large multicenter cohort of resected patients showed that age does not affect the long-term prognosis even if after 6 years from the hepatic resection the probability to be cure from this disease starts to increase for younger patients while starts to decrease for older patients. This was due to the onset of other age-specific causes of deaths (2).

\section{PROGNOSTIC FACTORS RELATED TO THE PRIMARY COLORECTAL TUMOR}

Many different factors related to the primary colorectal tumor are known to impact the long-term prognosis of resected CLM patients. Table 1 details such factors. Apart from T-status, $\mathrm{N}$-status, and poor differentiation, which are two well-known prognostic factors $(14,17-20)$, it is interesting to note that recently there was a countertendency about the location of the primary tumor. Historically, tumors in the rectum were thought to be the most aggressive $(7,8,14)$, but recently some studies underlined how tumors in the right colon may be the most aggressive (21). Indeed, it has been shown that the embryonic origin of the colon cancer (midgut versus hindgut) may be associated with different pattern of response to preoperative therapies and consequentially to different rates of survival. However, a note of caution should be considered when comparing such different studies, in which the proportion of synchronous CLM is different and the amount of missing data-specifically about the primary colorectal tumor data-is unknown. Yet, a true comparison would require at least a retrospective case-control study with a very large cohort of CLM patients with the same primary and secondary tumor

TABLE 1 | Traditional prognostic factors of colorectal liver metastases patients.

Factor

Age (older versus younger)

Sex (male versus female)

Embryonic origin (midgut versus hindgut)

Advanced T-stage

Positive N-stage

Poor grading

Elevated carcinoembryonic antigen

Presence of extrahepatic disease

Elevated number of liver metastases

Size of liver metastases (larger versus smaller)

Synchronous versus metachronous disease burden submitted to the most similar systemic and loco-regional treatments.

\section{CARCINOEMBRYONIC ANTIGEN}

Even if disparate results are reported in the literature about its role, the level of carcinoembryonic antigen (CEA) is traditionally considered of importance both for the diagnosis as well as for the prognosis of CLM patients $(7,8,22-24)$. Indeed, CEA level was found to be an independent factor correlated with 5-year overall and disease-free survival $(22,23,25)$. As a matter of fact, CEA is routinely used in the daily clinical practice to monitor the presence of disease recurrence and to assess the response to SC $(23,25)$. CEA represents the serum marker used as a surrogate of the biology of the disease. And, in the lack of more personalized and more sophisticated markers, it should be always tested.

\section{PROGNOSTIC FACTORS RELATED TO THE CLM}

Table 1 details the traditional prognostic factors of CLM patients. Tumor number, tumor size, bilobar involvement, and status of the resection margin affect the survival $(2,14,15,26)$. Even if it is reasonable that these variables affect survival, they are of limited utility in the daily clinically practice. The use of only these variables does not allow to stratify the long-term outcome especially in the current era of modern and efficient SC $(15,27,28)$. Similar considerations may be done for the histopathologic features, such as fibrous pseudocapsule formation, the degree of fibrosis around the metastases, single- versus confluent-node growing, infiltrative versus expansive type of growth, and invasion of intrahepatic vascular structures (29-31). All these features are important and informative, but they do not have an immediate translation in the daily clinical practice.

In general, metachronous CLM are associated with better outcome in comparison with synchronous CLM (14, 15, 32-34). However, many other studies reported similar outcome for synchronous and metachronous CLM $(26,27,35,36)$. This contradictory result may be explained with different types of therapies, either systemic or loco-regional, and different adopted definitions of metachronous CLM. Notably, in another large multicenter cohort of resected CLM, synchronous CLM resulted to significantly and independently impact the overall and diseasefree survival (2). However, synchronous presentation of CLMs should not affect the decision to operate, but should influence the timing of resection, particularly in patients at high risk for recurrence meaning that perioperative SC should be always considered in those patients.

\section{SURGICAL MARGIN}

It is noteworthy to affirm that the determination of margin width should be based on intraoperative ultrasound findings rather than on the liver palpation or just on what can be seen on preoperative images (37-39). Having said that, the surgical margin of CLM is always a subject of debate among experts. If microscopic negative 
margin (R0) is desirable in liver surgery, it should be considered the primary endpoint in any liver resection, and in the past years some works have supported that microscopic positive margin (R1), either parenchymal or vascular, may be oncologically adequate in some specific subgroups of patients $(38,40,41)$. Conversely, other authors have showed that R1 resections should be avoided being associated with decreased survival (7, 25, 42-46). In a large cohort of CLM patients, Pawlik et al. (47) reported that $1 \mathrm{~mm}$ of negative margin was enough to ensure a good outcome. Nowadays, experts agree that the biology of the disease rather than the millimeter of the surgical margin dictates the prognosis of CLM patients (48). In regard to R1 resections, in particular, with regards to R1-vascular resections that are the detachment of the tumor from major intrahepatic vessels, it should be noted that they were found to be oncologically adequate as R0 resections (41). Moreover, those types of resections were conducted on patients otherwise marginally resectable because of advanced intrahepatic tumor burden. In other words, R1 resections may be better than no resections (41). Finally, it should be noted that the comparison among different CLM patients belonging to different studies is difficult. The differences in SC regimens, in intra- and extra-hepatic tumor burden, and in the statistical prognostic models used may, at least in part, explain the different conclusions $(49,50)$.

\section{EXTRAHEPATIC DISEASE}

The presence of extrahepatic disease, especially if multiple, represents not only a bad prognostic factor but also a contraindication for liver resection. As for the surgical margin, also for extrahepatic disease the literature includes studies with disparate results. Elias et al. (51) showed that the number of CLM may be prognostically more important than the site of extrahepatic disease. Conversely, other authors reported that the site of extrahepatic disease should be taken into account (52). Yet, it is generally accepted that the presence of lung metastases is better than distant lymph nodes metastases (53). A given patient with lung metastases, even multiple, may be treated with wedge resections and achieve adequate survival (54-57).

\section{RAS AND RAF GENES}

KRAS, HRAS, and NRAS, belong to the family of GTPases. When activated, KRAS can induce a cascade of mitogen-activated protein kinases that transfers signals from the cell membrane to the nucleus. The RAS gene products activate proteins in the RAF family, which consists of the ARAF, BRAF, and RAF-1 members (58). The importance around RAS mutations, rely on the possibility to predict resistance to the EGFR-targeted monoclonal antibodies. Such resistance may be seen in early stages as well as in advanced stages of the disease with an estimated prevalence up to $44 \%$ of CLM patients $(59,60)$. Several authors have reported significant associations between RAS mutations and survival showing that its molecular determination should be nowadays part of the CLM patient evaluation (61-65). In regard to BRAF mutations, they are reported as low as up to $2 \%$ of CLM patients (58). Nevertheless, has been shown that such mutations are independently associated with worse survival $(58,66-68)$.

\section{THE ROLE OF THE HOST IMMUNE SYSTEM}

Among the variables contributing to different clinical outcomes of tumors, the host immune responses certainly play a key role $(10,11)$. Under homeostatic conditions human adult liver contains $10^{10}$ lymphocytes, with the majority of these cells being cytotoxic T and NK cells $(69,70)$. Healthy human liver is a dynamic organ, undergoing constant inflammation in the maintenance of homeostasis (71). Elevated levels of chemokines, such as CCL5, CCL2, and IL-8 facilitate leukocyte accumulation (72) and correlate to the increased levels of innate $\mathrm{T}$ cells, NK cells, and monocytes seen in healthy liver (73). Yet, others and we have reported that a highly functional and unique subset of NK cells physiologically resides in the hepatic sinusoids and these cells can comprise up to $50 \%$ of the total hepatic lymphocyte population $(70,74)$. Hence, understanding the mechanisms inducing the infiltration of these anti-tumor cells into the CLM is highly relevant both for the estimation of the prognosis and for the development of novel and more effective therapies. A large amount of data that are available in the literature support that the infiltrating leukocytes have a major effect on the clinical outcome $(13,75-79)$. The CLM patient is not an exception. The tissue microenvironment of metastatic liver is characterized by increased levels of inflammatory cytokines and perturbation of chemokine expression. Molecular cross-talk between tumor-infiltrating immune cells, local tissue-resident immune cell populations, stromal cells, and malignant epithelial cells determines the success of metastatic disease (80). This increased local inflammation may disrupt the normal hepatic immune cell repertoire and subsequent tumor surveillance (81). And, the presence of tumor-infiltrating immune cells has been associated with prolonged survival in patients with colon cancer $(12,13$, $82-86)$. Consistently, it is in fact well known that human liver is highly enriched of cytotoxic anti-tumor lymphocytes including $\mathrm{T}$ and NK cells that exert immune-surveillance against cancer $(70,87,88)$. Recently, also our group has showed how the presence of intratumoral infiltration of NK cells was an independent prognostic factor favoring overall survival after resection of CLM (89). Those data and results support how the host immune system represents an emerging hallmark of cancer (90) which should not be any more left to exploratory translational researches while it should be routinely considered in daily clinical practice. Indeed, in the past years the tumor microenvironment has been target of many studies aiming to find new promising therapies for solid tumors. Immune checkpoint inhibitors, such as ipilimumab and nivolumab have been introduced also for CLM patients with interesting findings (91). Yet, understanding the biological mechanisms by which a given host immune contexture might be more favorable against colorectal cancer and CLM is the fundamental step that must be achieved to introduce innovative immunotherapies. More efforts should be done to identify which immunological factors are related to the tumors cells, which are related to the host, and how those factors interact to each other. Last but the not least, the role of loco-regional and SC in altering such factors should be one of the researchers' priorities. Yet, in large cohort of colorectal tumors, a gene-gene correlation 
TABLE 2 | Immune intrigue of colorectal liver metastases patients.

\begin{tabular}{|c|c|c|c|}
\hline Cell type & Location & Role & Prognosis \\
\hline $\begin{array}{l}\text { T cell (CD4+ } \\
\text { and CD8+) }\end{array}$ & $\begin{array}{l}\text { Intratumoral; } \\
\text { invasive margin }\end{array}$ & $\begin{array}{l}\text { Specific tumor cell killing activity } \\
\text { Release cytotoxic cytokines }\end{array}$ & + \\
\hline Treg & $\begin{array}{l}\text { Intratumoral; } \\
\text { invasive margin }\end{array}$ & $\begin{array}{l}\text { Suppress anticancer immune } \\
\text { responses }\end{array}$ & - \\
\hline Macrophage & $\begin{array}{l}\text { Intratumoral; } \\
\text { invasive margin }\end{array}$ & $\begin{array}{l}\text { M1: tumor suppression and } \\
\text { immune stimulation } \\
\text { M2: malignant progression and } \\
\text { suppressed CTL }\end{array}$ & $+/-$ \\
\hline NK & $\begin{array}{l}\text { Intratumoral; } \\
\text { invasive margin }\end{array}$ & $\begin{array}{l}\text { Cytotoxic activity and cytokine } \\
\text { production }\end{array}$ & + \\
\hline MDSC & $\begin{array}{l}\text { Intratumoral; } \\
\text { invasive margin }\end{array}$ & $\begin{array}{l}\text { Repression of the effector } \\
\text { function of } \\
\text { T lymphocytes and NK cells }\end{array}$ & - \\
\hline DC & $\begin{array}{l}\text { Intratumoral; } \\
\text { invasive margin }\end{array}$ & $\begin{array}{l}\text { Processing and presentation } \\
\text { of tumor-associated antigens }\end{array}$ & + \\
\hline
\end{tabular}

Treg, T regulatory; CTL, cytotoxic T lymphocytes; NK, natural killer; MDSC, myeloidderived suppressor cell; DC; dendritic cells.

network was built to understand which genes may be associated with anti-tumor response (92). As many as 65 different genes were identified, but interestingly most of them were linked to the host immune functionality ( $\mathrm{T}$ and $\mathrm{B}$ cell activation, inflammatory response, $\mathrm{T}$ and $\mathrm{B}$ cells differentiation, adhesion- and migrationassociated chemokines, activation of NK cells), which mean that certainly the immune system deserves further attention.

Table 2 details the immune intrigue that may be part of the liver tissue of CLM patients. Each of the cells represents a potential target for decoding the clinical heterogeneity of CLM patients, for developing new biomarkers, and consequently for developing new personalized immunotherapies.

Notably, myeloid-derived suppressor cells (MDSCs) are immature myeloid cells present in tumor-bearing hosts and can be subdivided into monocytic MDSCs (M-MDSCs) and granulocytic MDSCs (G-MDSCs) (93). Within tumors, M-MDSCs, but not G-MDSCs, rapidly differentiate into TAMs (94). Therefore, TAMs may originate from monocytes, by local proliferation, and from M-MDSCs.

Nielsen et al. (95) postulated a potential role in colon cancer also other immune cells, such as mast cells. Indeed, those cells were found to be independently associated with favorable outcome in a large series of patients. However, data are limited and further studies on mast cells should be carried out.

Interestingly, there are also associations between angiogenesis and the immune system. Notably, the significance of angiogenesis as a prognostic factor has already been investigated in colorectal cancer (96). VEGF plays a key role in angiogenesis, a highly complex process that is essential for tumor growth. Studies showed that VEGF has a significant prognostic role by affecting the tumor's metastatic potential and by correlating with response to treatment and survival (97). Two signaling pathways play important role in the growth and metastatic potential of human colorectal cancers including the VEGF and
EGFR pathways. EGF is one of the natural ligands of the EGFR, which is a transmembrane tyrosine kinase receptor critical to normal cell proliferation and differentiation. An increased level of EGFR seems to be an important factor driving the aggressive behavior of cancer cells (98). Several studies showed a relationship between high EGFR levels and high-grade tumors and poor prognosis (99). And in line with this, some experimental data showed that the blocking of the EGFR pathway was associated with an increased immune infiltration in solid cancers $(100,101)$. In this regard, several in vitro and in vivo models have shown that the masking of EGFR with a specific blocking monoclonal $\mathrm{Ab}(\mathrm{mAb})$ inhibits tumor proliferation, induces terminal cellular differentiation, and modulates chemo- and radio-sensitivity (102). Recently, it has been also reported that the inhibition of the EGFR signaling pathway facilitates the activation of immune cells and their recruitment to tumor sites via the production of several cytokines and chemokines (100). This is particularly relevant for NK cells, as studies have shown that the use of a blocking anti-EGFR mAb stimulates these innate immune effector lymphocytes and induces antibody-dependent cell cytotoxicity. At the same time, the refractory effect of the tumor against this biological compound may be explained by the induction of mechanisms that the tumor can use to evade immune responses. Pre-clinical in vivo models have shown the existence of inducible mice carrying altered oncogenic and immunological pathways that are resistant to the inhibition of EGFR (103-105). Hence, since neo-adjuvant therapies in CLM adopt conventional chemotherapy agents (i.e., oxaliplatin and irinotecan), which are associated with biological drugs targeting different pathogenic signaling pathways in CLM, clinicians have to consider all possible mechanisms of oncogenic and immunological tumor escape in order to provide the most effective and customizable therapeutic options.

\section{CONCLUSION}

Survival following resection of CLM depends on several clinical, pathological, and molecular factors. Apart from those factors related to the tumor, both the primary colorectal and the CLM, there is the need to accurately consider also those factors related to the host immune system, which certainly plays an important role. Yet, the burgeoning data about the immunological intrigue of CLM patients deserve to consider on a single-patient basis with the aim to be more sensitive in the prognostication as well as to introduce more efficient immune therapies. Thus, the sampling and analysis of the tissue microenvironment of CLM is essential and should be part of the standard histological examination of such patients.

\section{AUTHOR CONTRIBUTIONS}

MD: conception and design. MD, AL, and LT: methodology. $\mathrm{MD}, \mathrm{AL}, \mathrm{LT}, \mathrm{CS}$, and BF: review of the literature. MD: writing, review, and/or revision of the manuscript. MR and GT: study supervision. 


\section{REFERENCES}

1. Siegel R, Naishadham D, Jemal A. Cancer statistics, 2013. CA Cancer J Clin (2013) 63:11-30. doi:10.3322/caac.21166

2. Cucchetti A, Ferrero A, Cescon M, Donadon M, Russolillo N, Ercolani G, et al. Cure model survival analysis after hepatic resection for colorectal liver metastases. Ann Surg Oncol (2015) 22:1908-14. doi:10.1245/ s10434-014-4234-0

3. Nordlinger B, Sorbye H, Glimelius B, Poston GJ, Schlag PM, Rougier P, et al. Perioperative chemotherapy with FOLFOX4 and surgery versus surgery alone for resectable liver metastases from colorectal cancer (EORTC Intergroup trial 40983): a randomised controlled trial. Lancet (2008) 371:1007-16. doi:10.1016/S0140-6736(08)60455-9

4. Adam R, De Gramont A, Figueras J, Guthrie A, Kokudo N, Kunstlinger F, et al. The oncosurgery approach to managing liver metastases from colorectal cancer: a multidisciplinary international consensus. Oncologist (2012) 17:1225-39. doi:10.1634/theoncologist.2012-0121

5. Folprecht G, Gruenberger T, Bechstein W, Raab HR, Weitz J, Lordick F, et al. Survival of patients with initially unresectable colorectal liver metastases treated with FOLFOX/cetuximab or FOLFIRI/cetuximab in a multidisciplinary concept (CELIM study). Ann Oncol (2014) 25:1018-25. doi:10.1093/ annonc/mdu088

6. Kopetz S, Chang GJ, Overman MJ, Eng C, Sargent DJ, Larson DW, et al. Improved survival in metastatic colorectal cancer is associated with adoption of hepatic resection and improved chemotherapy. J Clin Oncol (2009) 27(22):3677-83. doi:10.1200/JCO.2008.20.5278

7. Fong Y, Fortner J, Sun RL, Brennan MF, Blumgart LH. Clinical score for predicting recurrence after hepatic resection for metastatic colorectal cancer: analysis of 1001 consecutive cases. Ann Surg (1999) 230:309-18. doi:10.1097/00000658-199909000-00004

8. Nordlinger B, Guiguet M, Vaillant JC, Balladur P, Boudjema K, Bachellier P, et al. Surgical resection of colorectal carcinoma metastases to the liver. A prognostic scoring system to improve case selection, based on 1568 patients. Association Francaise de Chirurgie. Cancer (1996) 77:1254-62. doi:10.1002/ (SICI)1097-0142(19960401)77:7<1254::AID-CNCR5>3.0.CO;2-I

9. Rees M, Tekkis PP, Welsh FK, O’Rourke T, John TG. Evaluation of long-term survival after hepatic resection for metastatic colorectal cancer: a multifactorial model of 929 patients. Ann Surg (2008) 247:125-35. doi:10.1097/ SLA.0b013e31815aa2c2

10. Kanas GP, Taylor A, Primrose JN, Langeberg WJ, Kelsh MA, Mowat FS, et al. Survival after liver resection in metastatic colorectal cancer: review and meta-analysis of prognostic factors. Clin Epidemiol (2012) 4:283-301. doi:10.2147/CLEP.S34285

11. House AK, Watt AG. Survival and the immune response in patients with carcinoma of the colorectum. Gut (1979) 20:868-74. doi:10.1136/gut.20.10.868

12. Laghi L, Bianchi P, Miranda E, Balladore E, Pacetti V, Grizzi F, et al. CD3+ cells at the invasive margin of deeply invading (pT3-T4) colorectal cancer and risk of post-surgical metastasis: a longitudinal study. Lancet Oncol (2009) 10:877-84. doi:10.1016/S1470-2045(09)70186-X

13. Galon J, Costes A, Sanchez-Cabo F, Kirilovsky A, Mlecnik B, Lagorce-Pages C, et al. Type, density, and location of immune cells within human colorectal tumors predict clinical outcome. Science (2006) 313:1960-4. doi:10.1126/ science. 1129139

14. Scheele J, Stangl R, Altendorf-Hofmann A. Hepatic metastases from colorectal carcinoma: impact of surgical resection on the natural history. Br J Surg (1990) 77:1241-6. doi:10.1002/bjs.1800771115

15. Minagawa M, Makuuchi M, Torzilli G, Takayama T, Kawasaki S, Kosuge T, et al. Extension of the frontiers of surgical indications in the treatment of liver metastases from colorectal cancer: long-term results of our experience. Ann Surg (2000) 23:487-99. doi:10.1097/00000658-200004000-00006

16. Fong Y, Cohen AM, Fortner JG, Enker WE, Turnbull AD, Coit DG, et al. Liver resection for colorectal metastases. J Clin Oncol (1997) 15:938-46. doi:10.1200/JCO.1997.15.3.938

17. Lise M, Bacchetti S, Da Pian P, Nitti D, Pilati P. Patterns of recurrence after resection of colorectal liver metastases: prediction by models of outcome analysis. World J Surg (2001) 25:638-44. doi:10.1007/s002680020138

18. Nordlinger B, Quilichini MA, Parc R, Hannoun L, Delva E, Huguet C, et al. Hepatic resection for colorectal liver metastases. Influence on survival of preoperative factors and surgery for recurrences in 80 patients. Ann Surg (1987) 205:256-63. doi:10.1097/00000658-198703000-00007

19. Zieren HU, Müller JM, Zieren J, Pichlmaier H. The impact of patient's age on surgical therapy of colorectal liver metastases. Int Surg (1993) 78:288-91.

20. Ambiru S, Miyazaki M, Isono T, Ito H, Nakagawa K, Shimizu H, et al. Hepatic resection for colorectal metastases: analysis of prognostic factors. Dis Colon Rectum (1999) 42:632-9. doi:10.1007/BF02234142

21. Yamashita S, Brudvik KW, Kopetz SE, Maru D, Clarke CN, Passot G, et al. Embryonic origin of primary colon cancer predicts pathologic response and survival in patients undergoing resection for colon cancer liver metastases. Ann Surg (2016) 267(3):514-20. doi:10.1097/SLA.0000000000002087

22. Mann CD, Metcalfe MS, Leopardi LN, Maddern GJ. The clinical risk score: emerging as a reliable preoperative prognostic index in hepatectomy for colorectal metastases. Arch Surg (2004) 139:1168-72. doi:10.1001/ archsurg.139.11.1168

23. Tan MC, Butte JM, Gonen M, Kemeny N, Fong Y, Allen PJ, et al. Prognostic significance of early recurrence: a conditional survival analysis in patients with resected colorectal liver metastasis. HPB (2013) 15:803-13. doi:10.1111/ hpb. 12136

24. Aldrighetti L, Castoldi R, Di Palo S, Arru M, Stella M, Orsenigo E, et al. Prognostic factors for long-term outcome of hepatic resection for colorectal liver metastases. Chir Ital (2005) 57:555-70.

25. John SK, Robinson SM, Rehman S, Harrison B, Vallance A, French JJ, et al. Prognostic factors and survival after resection of colorectal liver metastasis in the era of preoperative chemotherapy: an 11-year single-centre study. Dig Surg (2013) 30:293-301. doi:10.1159/000354310

26. Doci R, Gennari L, Bignami P, Montalto F, Morabito A, Bozzetti F. One hundred patients with hepatic metastases from colorectal cancer treated by resection: analysis of prognostic determinants. Br J Surg (1991) 78:797-801. doi:10.1002/bjs.1800780711

27. Taylor M, Forster J, Langer B, Taylor BR, Greig PD, Mahut C. A study of prognostic factors for hepatic resection for colorectal metastases. Am J Surg (1997) 173:467-71. doi:10.1016/S0002-9610(97)00020-2

28. Nakamura S, Sakaguchi S, Nishiyama R, Suzuki S, Yokoi Y, Baba S, et al. Aggressive repeat liver resection for hepatic metastases of colorectal carcinoma. Surg Today (1992) 22:260-4. doi:10.1007/BF00308832

29. Yamamoto J, Shimada K, Kosuge T, Yamasaki S, Sakamoto M, Fukuda H. Factors influencing survival of patients undergoing hepatectomy for colorectal metastases. Br J Surg (1999) 86:332-7. doi:10.1046/j.1365-2168.1999.01030.x

30. Yasui K, Hirai T, Kato T, Torii A, Uesaka K, Morimoto T, et al. A new macroscopic classification predicts prognosis for patient with liver metastases from colorectal cancer. Ann Surg (1997) 226:582-6. doi:10.1097/00000658-199711000-00002

31. Nagashima I, Oka T, Hamada C, Naruse K, Osada T, Muto T. Histopathological prognostic factors influencing long-term prognosis after surgical resection for hepatic metastases from colorectal cancer. Am J Gastroenterol (1999) 94:739-43. doi:10.1111/j.1572-0241.1999.00945.x

32. Jenkins LT, Millikan KW, Bines SD, Staren ED, Doolas A. Hepatic resection for metastatic colorectal cancer. Am Surg (1997) 63:605-10.

33. Sugihara K, Hojo K, Moriya Y, Yamasaki S, Kosuge T, Takayama T. Pattern of recurrence after hepatic resection for colorectal metastases. Br J Surg (1993) 80:1032-5. doi:10.1002/bjs. 1800800837

34. Nuzzo G, Giuliante F, Giovannini I, Tebala GD, Clemente G, Vellone M. Resection of hepatic metastases from colorectal cancer. Hepatogastroentero$\log y$ (1997) 44:751-9.

35. Fortner JG, Silva JS, Golbey RB, Cox EB, Maclean BJ. Multivariate analysis of a personal series of 247 consecutive patients with liver metastases from colorectal cancer. I. Treatment by hepatic resection. Ann Surg (1984) 199:306-16. doi:10.1097/00000658-198403000-00010

36. Holm A, Bradley E, Aldrete JS. Hepatic resection of metastasis from colorectal carcinoma. Morbidity, mortality, and pattern of recurrence. Ann Surg (1989) 209:428-34. doi:10.1097/00000658-198904000-00007

37. Torzilli G, Makuuchi M. Intraoperative ultrasonography in liver cancer. Surg Oncol Clin N Am (2003) 12:91-103. doi:10.1016/S1055-3207(02)00084-4

38. Torzilli G, Montorsi M, Donadon M, Palmisano A, Del Fabbro D, Gambetti A, et al. "Radical but conservative" is the main goal for ultrasonography-guided liver resection: prospective validation of this approach. J Am Coll Surg (2005) 201:517-28. doi:10.1016/j.jamcollsurg.2005.04.026 
39. Torzilli G. An Atlas. 1st ed. Milan: Springler-Verlag (2014). 280 p.

40. de Haas RJ, Wicherts DA, Flores E, Azoulay D, Castaing D, Adam R. R1 resection by necessity for colorectal liver metastases: is it still a contraindication to surgery? Ann Surg (2008) 248:626-37. doi:10.1097/SLA.0b013e31818a07f1

41. Viganò L, Procopio F, Cimino MM, Donadon M, Gatti A, Costa G, et al. Is tumor detachment from vascular structures equivalent to R0 resection in surgery for colorectal liver metastases? An observational cohort. Ann Surg Oncol (2016) 23:1352-60. doi:10.1245/s10434-015-5009-y

42. Tranchart H, Chirica M, Faron M, Balladur P, Lefevre LB, Svrcek M, et al. Prognostic impact of positive surgical margins after resection of colorectal cancer liver metastases: reappraisal in the era of modern chemotherapy. World J Surg (2013) 37:2647-54. doi:10.1007/s00268-013-2186-3

43. Weber JC, Nakano H, Bachellier P, Oussoultzoglou E, Inoue K, Shimura H, et al. Is a proliferation index of cancer cells a reliable prognostic factor after hepatectomy in patients with colorectal liver metastases? Am J Surg (2001) 182:81-8. doi:10.1016/S0002-9610(01)00656-0

44. Figueras J, Burdio F, Ramos E, Torras J, Llado L, Lopez-Ben S, et al. Effect of subcentimeter nonpositive resection margin on hepatic recurrence in patients undergoing hepatectomy for colorectal liver metastases. Evidences from 663 liver resections. Ann Oncol (2007) 18:1190-5. doi:10.1093/annonc/ mdm106

45. Are C, Gonen M, Zazzali K, Dematteo RP, Jarnagin WR, Fong Y, et al. The impact of margins on outcome after hepatic resection for colorectal metastasis. Ann Surg (2007) 246:295-300. doi:10.1097/SLA.0b013e31811ea962

46. Elias D, Lasser P, Rougier P, Ducreux M, Bognel C, Roche A. Frequency, technical aspects, results, and indications of major hepatectomy after prolonged intra-arterial hepatic chemo-therapy for initially unresectable hepatic tumors. J Am Coll Surg (1995) 180:213-9.

47. Pawlik TM, Scoggins CR, Zorzi D, Abdalla EK, Andres A, Eng C, et al. Effect of surgical margin status on survival and site of recurrence after hepatic resection for colorectal metastases. Ann Surg (2005) 241:715-22. doi:10.1097/01.sla.0000160703.75808.7d

48. Pawlik TM, Vauthey JN. Surgical margins during hepatic surgery for colorectal liver metastases: complete resection not millimeters defines outcome. Ann Surg Oncol (2008) 15:677-9. doi:10.1245/s10434-007-9703-2

49. Andreou A, Aloia TA, Brouquet A, Dickson PV, Zimmitti G, Maru DM, et al. Margin status remains an important determinant of survival after surgical resection of colorectal liver metastases in the era of modern chemotherapy. Ann Surg (2013) 257:1079-88. doi:10.1097/SLA.0b013e318283a4d1

50. Poultsides GA, Schulick RD, Pawlik TM. Hepatic resection for colorectal metastases: the impact of surgical margin status on outcome. HPB (2010) 12:43-9. doi:10.1111/j.1477-2574.2009.00121.x

51. Elias D, Liberale G, Vernerey D, Pocard M, Ducreux M, Boige V, et al. Hepatic and extrahepatic colorectal metastases: when resectable, their localization does not matter, but their total number has a prognostic effect. Ann Surg Oncol (2005) 12:900-9. doi:10.1245/ASO.2005.01.010

52. Carpizo DR, Are C, Jarnagin W, Dematteo R, Fong Y, Gönen M, et al. Liver resection for metastatic colorectal cancer in patients with concurrent extrahepatic disease: results in 127 patients treated at a single center. Ann Surg Oncol (2009) 16:2138-46. doi:10.1245/s10434-009-0493-6

53. Pulitanò $\mathrm{C}$, Bodingbauer $\mathrm{M}$, Aldrighetti $\mathrm{L}$, de Jong $\mathrm{MC}$, Castillo $\mathrm{F}$, Schulick RD, et al. Liver resection for colorectal metastases in presence of extrahepatic disease: results from an international multi-institutional analysis. Ann Surg Oncol (2011) 18:1380-8. doi:10.1245/s10434-010-1459-4

54. Inoue M, Kotake Y, Nakagawa K, Fujiwara K, Fukuhara K, Yasumitsu T. Surgery for pulmonary metastases from colorectal carcinoma. Ann Thorac Surg (2000) 70:380-3. doi:10.1016/S0003-4975(00)01417-X

55. Sakamoto T, Tsubota N, Iwanaga K, Yuki T, Matsuoka H, Yoshimura M. Pulmonary resection for metastases from colorectal cancer. Chest (2001) 119:1069-72. doi:10.1378/chest.119.4.1069

56. Mansel JK, Zinsmeister AR, Pairolero PC, Jett JR. Pulmonary resection of metastatic colorectal adenocarcinoma. A ten year experience. Chest (1986) 89:109-12. doi:10.1378/chest.89.1.109

57. Inoue $M$, Ohta $M$, Iuchi $K$, Matsumura $A$, Ideguchi $K$, Yasumitsu $T$, et al. Benefits of surgery for patients with pulmonary metastases from colorectal carcinoma. Ann Thorac Surg (2004) 78:238-44. doi:10.1016/j. athoracsur.2004.02.017

58. Fransén K, Klintenäs M, Osterström A, Dimberg J, Monstein HJ, Söderkvist P. Mutation analysis of the BRAF, ARAF and RAF-1 genes in human colorectal adenocarcinomas. Carcinogenesis (2004) 25:527-33. doi:10.1093/carcin/ bgh049

59. Linardou H, Dahabreh IJ, Kanaloupiti D, Siannis F, Bafaloukos D, Kosmidis P, et al. Assessment of somatick-RAS mutations as a mechanism associated with resistance to EGFR-targeted agents: a systematic review and meta-analysis of studies in advanced non-small-cell lung cancer and metastatic colorectal cancer. Lancet Oncol (2008) 9:962-72. doi:10.1016/S1470-2045(08)70206-7

60. Bouchahda M, Adam R, Giacchetti S, Castaing D, Brezault-Bonnet C, Hauteville D, et al. Rescue chemotherapy using multidrug chrono-modulated hepatic arterial infusion for patients with heavily pretreated metastatic colorectal cancer. Cancer (2009) 115:4990-9. doi:10.1002/cncr.24549

61. Kastrinakis WV, Ramchurren N, Maggard M, Steele G, Summerhayes IC. K-ras status does not predict successful hepatic resection of colorectal cancer metastasis. Arch Surg (1995) 130:9-14. doi:10.1001/archsurg. 1995.01430010011001

62. Kato M, Ito Y, Kobayashi S, Isono K. Detection of DCC and Ki-ras gene alterations in colorectal carcinoma tissue as prognostic markers for liver metastatic recurrence. Cancer (1996) 77:1729-35. doi:10.1002/ (SICI) 1097-0142(19960415)77:8+<1729::AID-CNCR23>3.0.CO;2-Z

63. Petrowsky H, Sturm I, Graubitz O, Kooby DA, Staib-Sebler E, Gog C, et al. Relevance of Ki-67 antigen expression and K-ras mutation in colorectal liver metastases. Eur J Surg Oncol (2001) 27:80-7. doi:10.1053/ejso. 2000.1029

64. Russo A, Migliavacca M, Bazan V, Maturi N, Morello V, Dardanoni G, et al. Prognostic significance of proliferative activity, DNA-ploidy, p53 and Ki-ras point mutations in colorectal liver metastases. Cell Prolif (1998) 31:139-53. doi:10.1046/j.1365-2184.1998.00116.x

65. Schimanski CC, Linnemann U, Berger MR. Sensitive detection of K-ras mutations augments diagnosis of colorectal cancer metastases in the liver. Cancer Res (1999) 59:5169-75.

66. Huang CJ, Teng HW, Chien CC, Lin JK, Yang SH. Prognostic significance of C-reactive protein polymorphism and KRAS/ BRAF in synchronous liver metastasis from colorectal cancer. PLoS One (2013) 8:e65117. doi:10.1371/ journal.pone. 0065117

67. Teng HW, Huang YC, Lin JK, Chen WS, Lin TC, Jiang JK, et al. BRAF mutation is a prognostic biomarker for colorectal liver metastasectomy. J Surg Oncol (2012) 106:123-9. doi:10.1002/jso.23063

68. Popovici V, Budinska E, Tejpar S, Weinrich S, Estrella H, Hodgson G, et al. Identification of a poor-prognosis BRAF-mutant-like population of patients with colon cancer. J Clin Oncol (2012) 30:1288-95. doi:10.1200/ JCO.2011.39.5814

69. Racanelli V, Rehermann B. The liver as an immunological organ. Hepatology (2006) 43:S54-62. doi:10.1002/hep.21060

70. Hudspeth K, Donadon M, Cimino M, Pontarini E, Tentorio P, Preti M, et al. Human liver-resident CD56(bright)/CD16(neg) NK cells are retained within hepatic sinusoids via the engagement of CCR5 and CXCR6 pathways. J Autoimmun (2016) 66:40-50. doi:10.1016/j.jaut.2015.08.011

71. Robinson MW, Harmon C, O'Farrelly C. Liver immunology and its role in inflammation and homeostasis. Cell Mol Immunol (2016) 13:267-76. doi: $10.1038 / \mathrm{cmi} .2016 .3$

72. Muthuswamy R, Berk E, Junecko BF, Zeh HJ, Zureikat AH, Normolle D, et al. NF- $\mathrm{kB}$ hyperactivation in tumor tissues allows tumor-selective reprogramming of the chemokine microenvironment to enhance the recruitment of cytolytic T effector cells. Cancer Res (2012) 72:3735-43. doi:10.1158/00085472.CAN-11-4136

73. Brackett CM, Kojouharov B, Veith J, Greene KF, Burdelya LG, Gollnick SO, et al. Toll-like receptor-5 agonist, entolimod, suppresses metastasis and induces immunity by stimulating an NK-dendritic-CD8+ T-cell axis. Proc Natl Acad Sci U S A (2016) 113:E874-83. doi:10.1073/pnas.1521359113

74. Marquardt N, Beziat V, Nystrom S, Hengst J, Ivarsson MA, Kekalainen E, et al. Cutting edge: identification and characterization of human intrahepatic CD49a+ NK cells. JImmunol (2015) 194:2467-71. doi:10.4049/ jimmunol.1402756

75. Dunn GP, Old LJ, Schreiber RD. The three Es of cancer immunoediting. Annu Rev Immunol (2004) 22:329-60. doi:10.1146/annurev.immunol. 22.012703.104803

76. Koebel CM, Vermi W, Swann JB, Zerafa N, Rodig SJ, Old LJ, et al. Adaptive immunity maintains occult cancer in an equilibrium state. Nature (2007) 450:903-7. doi:10.1038/nature06309 
77. Schreiber RD, Old LJ, Smyth MJ. Cancer immunoediting: integrating immunity's roles in cancer suppression and promotion. Science (2011) 331:1565-70. doi:10.1126/science.1203486

78. Shankaran V, Ikeda H, Bruce AT, White JM, Swanson PE, Old LJ, et al. IFN $\gamma$ and lymphocytes prevent primary tumour development and shape tumour immunogenicity. Nature (2001) 410:1107-11. doi:10.1038/35074122

79. Mlecnik B, Tosolini M, Kirilovsky A, Berger A, Bindea G, Meatchi T, et al. Histopathologic-based prognostic factors of colorectal cancers are associated with the state of the local immune reaction. J Clin Oncol (2001) 29:610-8. doi:10.1200/JCO.2010.30.5425

80. Gajewski TF, Schreiber H, Fu YX. Innate and adaptive immune cells in the tumor microenvironment. Nat Immunol (2013) 14:1014-22. doi:10.1038/ ni. 2703

81. Hand F, Harmon C, Elliott LA, Caiazza F, Lavelle A, Maguire D, et al. Depleted polymorphonuclear leukocytes in human metastatic liver reflect an altered immune microenvironment associated with recurrent metastasis. Cancer Immunol Immunother (2018). doi:10.1007/s00262-018-2149-5

82. Ropponen KM, Eskelinen MJ, Lipponen PK, Alhava E, Kosma VM. Prognostic value of tumour-infiltrating lymphocytes (TILs) in colorectal cancer. J Pathol (1997)182:318-24.doi:10.1002/(SICI)1096-9896(199707)182:3<318:: AID-PATH862>3.0.CO;2-6

83. Naito Y, Saito K, Shiiba K, Ohuchi A, Saigenji K, Nagura H, et al. CD8+ $\mathrm{T}$ cells infiltrated within cancer cell nests as a prognostic factor in human colorectal cancer. Cancer Res (1998) 58:3491-4.

84. Katz SC, Pillarisetty V, Bamboat ZM, Shia J, Hedvat C, Gonen M, et al. $\mathrm{T}$ cell infiltrate predicts long-term survival following resection of colorectal cancer liver metastases. Ann Surg Oncol (2009) 16:2524-30. doi:10.1245/ s10434-009-0585-3

85. Katz SC, Bamboat ZM, Maker AV, Shia J, Pillarisetty VG, Yopp AC, et al. Regulatory $\mathrm{T}$ cell infiltration predicts outcome following resection of colorectal cancer liver metastases. Ann Surg Oncol (2013) 20:946-55. doi:10.1245/ s10434-012-2668-9

86. Salama P, Phillips M, Grieu F, Morris M, Zeps N, Joseph D, et al. Tumorinfiltrating FOXP3 $+\mathrm{T}$ regulatory cells show strong prognostic significance in colorectal cancer. JClin Oncol (2009) 27:186-92. doi:10.1200/ JCO.2008.18.7229

87. Doherty DG, Norris S, Madrigal-Estebas L, McEntee G, Traynor O, Hegarty JE, et al. The human liver contains multiple populations of NK cells, T cells, and CD3+CD56+ natural T cells with distinct cytotoxic activities and Th1, Th2, and Th0 cytokine secretion patterns. J Immunol (1999) 163:2314-21.

88. Hata K, Van Thiel DH, Herberman RB, Whiteside TL. Natural killer activity of human liver-derived lymphocytes in various liver diseases. Hepatology (1991) 14:495-503. doi:10.1002/hep.1840140315

89. Donadon M, Hudspeth K, Cimino M, Di Tommaso L, Preti M, Tentorio P, et al. Increased infiltration of natural killer and $\mathrm{T}$ cells in colorectal liver metastases improves patient overall survival. J Gastrointest Surg (2017) 21:1226-36. doi:10.1007/s11605-017-3446-6

90. Hanahan D, Weinberg RA. Hallmarks of cancer: the next generation. Cell (2011) 144:646-74. doi:10.1016/j.cell.2011.02.013

91. Mlecnik B, Bindea G, Angell HK, Maby P, Angelova M, Tougeron D, et al. Integrative analyses of colorectal cancer show immunoscore is a stronger predictor of patient survival than microsatellite instability. Immunity (2016) 44:698-711. doi:10.1016/j.immuni.2016.02.025

92. Mlecnik B, Tosolini M, Charoentong P, Kirilovsky A, Bindea G, Berger A, et al. Biomolecular network reconstruction identifies T-cell homing factors associated with survival in colorectal cancer. Gastroenterology (2010) 138:1429-40. doi:10.1053/j.gastro.2009.10.057

93. Marvel D, Gabrilovich DI. Myeloid-derived suppressor cells in the tumor microenvironment: expect the unexpected. J Clin Invest (2015) 125:3356-64. doi:10.1172/JCI80005
94. Kumar V, Patel S, Tcyganov E, Gabrilovich DI. The Nature of myeloid-derived suppressor cells in the tumor microenvironment. Trends Immunol (2016) 37:208-20. doi:10.1016/j.it.2016.01.004

95. Nielsen HJ, Hansen U, Christensen IJ, Reimert CM, Brünner N, Moesgaard F. Independent prognostic value of eosinophil and mast cell infiltration in colorectal cancer tissue. J Pathol (1999) 189:487-95. doi:10.1002/ (SICI)1096-9896(199912)189:4<487::AID-PATH484>3.0.CO;2-I

96. Akbulut H, Altuntas F, Akbulut KG, Ozturk G, Cindoruk M, Unal E, et al. Prognostic role of serum vascular endothelial growth factor, basic fibroblast growth factor and nitric oxide in patients with colorectal carcinoma. Cytokine (2002) 20:184-90. doi:10.1006/cyto.2002.1993

97. De Vita F, Orditura M, Lieto E, Infusino S, Morgillo F, Martinelli E, et al. Elevated perioperative serum vascular endothelial growth factor levels in patients with colon carcinoma. Cancer (2004) 100:270-8. doi:10.1002/ cncr.11911

98. Yarden Y, Sliwkowski MX. Untangling the ErbB signalling network. Nat Rev Mol Cell Biol (2001) 2:127-37. doi:10.1038/35052073

99. Kopp R, Rothbauer E, Ruge M, Arnholdt H, Spranger J, Muders M, et al. Clinical implications of the EGF receptor/ligand system for tumor progression and survival in gastrointestinal carcinomas: evidence for new therapeutic options. Recent Results Cancer Res (2003) 162:115-32. doi:10.1007/978-3-642-59349-9_10

100. Hoffmann TK, Schirlau K, Sonkoly E, Brandau S, Lang S, Pivarcsi A, et al. A novel mechanism for anti-EGFR antibody action involves chemokine-mediated leukocyte infiltration. Int J Cancer (2009) 124:2589-96. doi:10.1002/ ijc. 24269

101. Ito Y, Correll K, Zemans RL, Leslie CC, Murphy RC, Mason RJ. Influenza induces IL-8 and GM-CSF secretion by human alveolar epithelial cells through HGF/c-Met and TGF-alpha/EGFR signaling. Am J Physiol Lung Cell Mol Physiol (2015) 308:L1178-88. doi:10.1152/ajplung.00290. 2014

102. Mendelsohn J, Baselga J. Epidermal growth factor receptor targeting in cancer. Semin Oncol (2006) 33:369-85. doi:10.1053/j.seminoncol.2006. 04.003

103. Bier H, Hoffmann T, Haas I, van Lierop A. Anti-(epidermal growth factor) receptor monoclonal antibodies for the induction of antibody-dependent cell-mediated cytotoxicity against squamous cell carcinoma lines of the head and neck. Cancer Immunol Immunother (1998) 46:167-73. doi:10.1007/ s002620050475

104. Roda JM, Joshi T, Butchar JP, McAlees JW, Lehman A, Tridandapani S, et al. The activation of natural killer cell effector functions by cetuximab-coated, epidermal growth factor receptor positive tumor cells is enhanced by cytokines. Clin Cancer Res (2007) 13:6419-28. doi:10.1158/1078-0432. CCR-07-0865

105. Garrido G, Lorenzano P, Sanchez B, Beausoleil I, Alonso DF, Perez R, et al. $\mathrm{T}$ cells are crucial for the anti-metastatic effect of anti-epidermal growth factor receptor antibodies. Cancer Immunol Immunother (2007) 56:1701-10. doi:10.1007/s00262-007-0313-4

Conflict of Interest Statement: The authors declare that the research was conducted in the absence of any commercial or financial relationships that could be construed as a potential conflict of interest.

Copyright (c) 2018 Donadon, Lleo, Di Tommaso, Soldani, Franceschini, Roncalli and Torzilli. This is an open-access article distributed under the terms of the Creative Commons Attribution License (CC BY). The use, distribution or reproduction in other forums is permitted, provided the original author(s) and the copyright owner are credited and that the original publication in this journal is cited, in accordance with accepted academic practice. No use, distribution or reproduction is permitted which does not comply with these terms. 